\title{
Some new oribatids (Acarina, Oribatei) from the Rostov-Don region, Soviet Union
}

\section{Eero Karppinen \& M. P. Poltavskaja}

Karppinen, E. \& Poltavskaja, M. P. 1990: Some new oribatids (Acarina, Oribatei) from the Rostov-Don region, Soviet Union. - Entomol. Fennica 1:103-106.

The paper gives descriptions of a new genus, Infernobates gen. n., and three new species, Infernobates citelli sp. n., Graptoppia tanaitica sp. n. and Zetorchestes reticulatus $\mathrm{sp} . \mathrm{n}$.

Eero Karppinen,Zoological Museum,University ofHelsinki,SF-00100 Helsinki, Finland

M. P. Poltavskaja, Botanical Garden of Rostov State University, Lesoparkovaja 1, Rostov, GSP-7, USSR

Infernobates Karppinen \& Poltavskaja gen. n.

This new genus is closely related to the genus Kaszabobates Balogh 1972 (= Gobiella Balogh \& Mahunka 1965), but differs from it in the following characteristics (see Balogh \& Mahunka 1965):

- absence of flask-like figure on prodorsum between costulae

- less salient front edge of notogaster

- 10 pairs of notogastral setae (in Kaszabobates 14 pairs)

Type species Infernobates citelli Karppinen \& Poltavskaja sp. $n$.

\section{Infernobates citelli Karppinen \& Poltavskaja} sp. $\mathbf{n}$.

Fig. 1

Material: $1 \circ$ (holotype) $+92 \circ$ and $58 \sigma^{7}$ (paratypes) from Rostov-Don Botanical garden, grassy steppe (dominant Festuca), in holes of Citellus pygmaeus, depth 60-90 cm, 20.04.1984. 74 o and $61 \sigma^{7}$ (paratypes) from Askania-Nova
State Reserve, plot "Northern", grassy steppe (dominant Festuca), holes of Citellus pygmaeus, depth $80-130 \mathrm{~cm}$, 24.04.1985.

Colour yellow. Considerable differences have been found in the size of adult females. Length: large oo $0.350 \mathrm{~mm}$, small oㅇ $0.250-0.260 \mathrm{~mm}$, o $^{7} 0.260 \mathrm{~mm}$. Breadth: largc oᄋ $0.200 \mathrm{~mm}$, small oo and ơ $\sigma^{\top} 0.150 \mathrm{~mm}$.

Prodorsum: Length: large $\varnothing \odot 0.085 \mathrm{~mm}$, small ofo $0.070 \mathrm{~mm}$ and $\sigma^{7} \sigma^{7} 0.060 \mathrm{~mm}$. Breadth: 0.100 $\mathrm{mm}, 0.070$ and $0.060 \mathrm{~mm}$, respectively. The costulae are as in Kaszabobates kaszabi (Balogh \& Mahunka 1965). Between them is a smooth field. From the base of the costulae stretches a long, narrow, curved line. Sublamellar combs are also present. Exobothridial setae are situated on the rollers, which stretch from the lateral edges of the bases of the bothridia to the sublamellar combs. The sensillae are hairlike and haired (Fig. 1C), length: large $\odot \odot 0.070$, small $\varnothing \odot 0.040$ and $0^{7} \sigma^{7}$ $0.040 \mathrm{~mm}$. All setae of the prodorsum are hairy. Length of lamellar setae: large oo 0.025 , small oo 0.013 , and $\sigma^{\top} \sigma^{\top} 0.013 \mathrm{~mm}$; interlamellar setae: $0.060,0.025,0.025 \mathrm{~mm}$ and rostral setae: 0.050 , $0.026,0.026 \mathrm{~mm}$, respectively. 


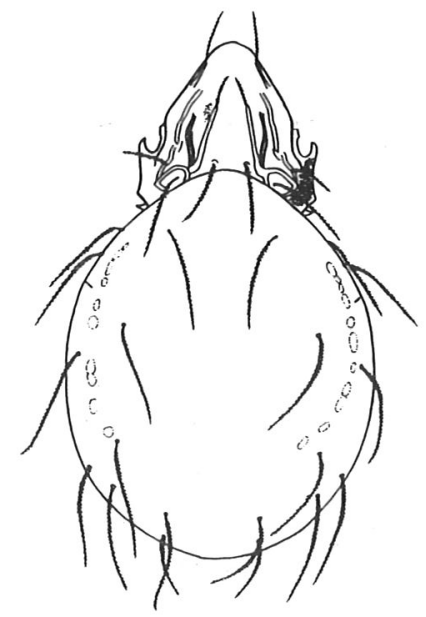

A

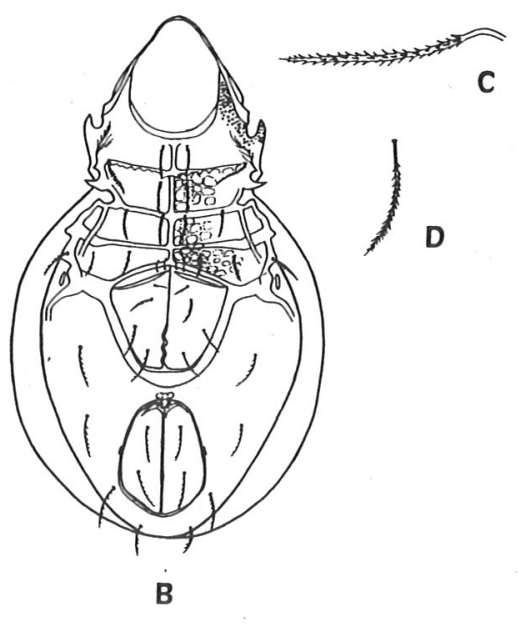

Fig. 1. Infernobates citelli Karppinen \& Poltavskaja sp. n. - A: dorsal side, B: ventral side, C: sensilla, D: hair of hysterosoma.
Notogaster: Length: large $\circ \circ 0.265 \mathrm{~mm}$, small ofo $0.180 \mathrm{~mm}$ and $\sigma^{7} \sigma^{7} 0.200 \mathrm{~mm}$. Breadth: 0.210 $\mathrm{mm}, 0.150 \mathrm{~mm}$ and $0.150 \mathrm{~mm}$, respectively. The front edge of the notogaster is rounded and covers the hind edge of the bothridia, seen from above. Its form is variable and may be less salient and almost straight in some specimens from the same collecting place, independently of size and sex. The notogastral setae are hairy (Fig. 1D), length: large 우 0.070, small 우 0.040, and $\sigma^{\top} \sigma^{7} 0.040 \mathrm{~mm}$.

Ventral side (Fig. 1B): Size of genital plate: $0.080 \times 0.075 \mathrm{~mm}, 0.050 \times 0.047 \mathrm{~mm}, 0.050 \times$ $0.047 \mathrm{~mm}$; size of anal plate: $0.095 \times 0.070 \mathrm{~mm}$, $0.070 \times 0.050 \mathrm{~mm}, 0.070 \times 0.050 \mathrm{~mm}$, in large $\propto$, small oo and $\sigma^{7} \sigma^{\prime}$, respectively. The 3 cranial pairs of genital setae are smaller than the others. The first two pairs are smooth and all the others hairy. Pori iad are in adanal position and located at the external edge of the anal plate.

\section{Graptoppia tanaitica Karppinen \& Poltavskaja sp. $n$.}

Fig. 2

Material: 1 (holotype) +2 o and $3 \sigma^{7}$ from Rostov-Don region, Mjasnikovsky district, village Nedvigowka, fallow, 1979; $10 q+15 \sigma^{7}$ from Rostov-Don Botanical garden, grassy steppe (dominant Festuca), 1985; $8 \circ+6 \sigma^{7}$ from Rostov-Don region, Martinovskaja district, local natural place "Grom-Gora" (Thunder Hill), 1985.
Colour yellow. Length: $0.220 \mathrm{~mm}$ (holotype and $o$ paratypes), $0.210 \mathrm{~mm}$ ( $\sigma^{7}$ paratypes). Breadth: $0.110 \mathrm{~mm}$ (holotype and $\circ$ paratypes), $0.095 \mathrm{~mm}$ ( (

Prodorsum: Length: $\odot 0.070 \mathrm{~mm}, \mathrm{O}^{7} 0.065$ mm; breadth: $\varnothing 0.060 \mathrm{~mm}, \bigcirc^{7} 0.055 \mathrm{~mm}$. Bothridia drop-like rounded. Costulae with a translamellar line with small hollows, in which lamellar setae are situated. Medial part of translamellar line between setae thinner than lateral parts. Setae of prodorsum smooth except sensillae, which are fusiform and unilaterally ciliated. Length of rostral setae: $\circ 0.018, \sigma^{\top} 0.015 \mathrm{~mm}$; lamellar setae: $ᄋ$ $0.012, \sigma^{7} 0.009 \mathrm{~mm}$; interlamellar setae: $\bigcirc 0.010$, $\sigma^{\top} 0.008 \mathrm{~mm}$; sensillae: o $0.030, \sigma^{\top} 0.025 \mathrm{~mm}$.

Notogaster: Length: o 0.150, o $0.145 \mathrm{~mm}$; breadth: o 0.115, o7 $0.095 \mathrm{~mm}$. Form ovoid. Humeral part with one pair of pori, in front of which is a hair rudiment. The same is also present in the type species of the family, G. foveolata (Balogh 1983). These hair rudiments may be characteristic of the genus (see Balogh 1983). Notogastral setae smooth.

Ventral side: Size of genital plate: $00.025 \times$ $0.023 \mathrm{~mm}$, or $^{7} 0.018 \times 0.016 \mathrm{~mm}$; anal plate: $\circ$ $0.038 \times 0.038 \mathrm{~mm}, \mathrm{O}^{7} 0.035 \times 0.035 \mathrm{~mm}$. Setae $\mathrm{ad}_{3}$ extend up to the level of the aggenital and ad-anal setae, so that all four setae form a horizon line between the genital and anal plates, at the same distance from both. 
Fig. 2. Graptoppia tanaitica Karppinen \& Poltavskaja sp. n. - A: dorsal view, B: ventral view, C: lateral view.

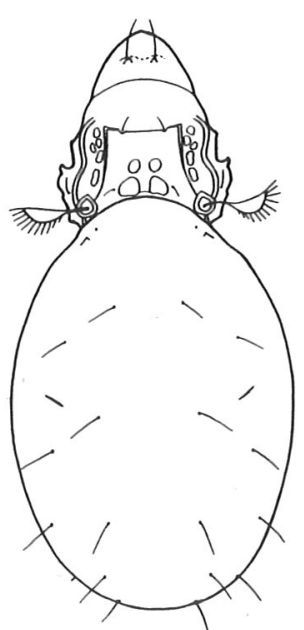

A

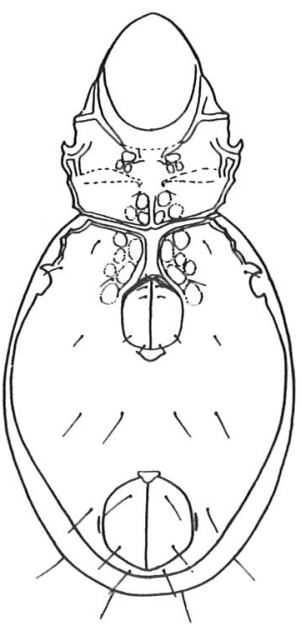

B

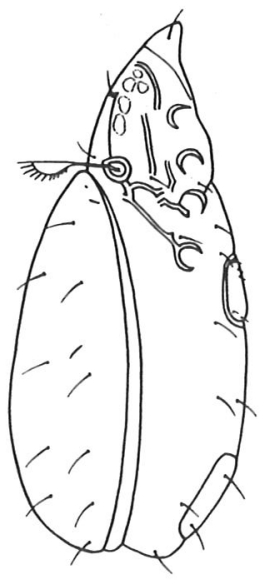

C
This new species differs most distinctly from G. foveolata (Balogh 1983) in the following characteristics:

- complete absence of apodemae IV

- greater relative size of genital and anal plates (Fig. 2B)

- form of costulae and translamellar line

- structure of lateral region of prodorsum

- sharp tip of sensillae

- form of bothridia

- smaller total size

\section{Zetorchestes reticulatus Karppinen \& Poltavskaja sp. $\mathbf{n}$.}

Fig. 3

Material: $1 \odot$ (holotype) $+1 \odot$ and $2 \sigma^{7}$ (paratypes) from Rostov-Don region, Martinovskaja district, local natural place "Grom-Gora" (Thunder Hill), grassy steppe (dominant Festuca), 10.05.85.

Colour brown. Length: $\odot$ (holotype) 0.480 $\mathrm{mm}$, o (paratype) $0.475 \mathrm{~mm}, \sigma^{7} \sigma^{7}$ (paratypes) 0.476-0.477 mm. Breadth: o (holotype) 0.310 $\mathrm{mm}$, ᄋ (paratype) $0.308 \mathrm{~mm}, \sigma^{\top} \sigma^{7}$ (paratypes) 0.305-0.308 mm.

Prodorsum: Length $0.170 \mathrm{~mm}$, breadth 0.200 $\mathrm{mm}$. Rostrum with rounded projection. Rostral setae (length $0.040 \mathrm{~mm}$ ) on long apophyses. Lamellae narrowing sharply in their middle part, turning sideways at the tip and ending in apophyses with long $(0.065 \mathrm{~mm})$ serrated lamellar setae (Fig. 3A and E). Sensillae $(0.070 \mathrm{~mm})$ fan-shaped wide and serrated, on a thin stem (Fig. 3D). Bothridia with a tooth on the front edge (Fig. 3D). Interlamellar setae $(0.035 \mathrm{~mm})$ lanceolate, with small thorns on their surface.

Notogaster: Length $0.310 \mathrm{~mm}$, breadth 0.310 $\mathrm{mm}$. Notogastral setae lanceolate with small thorns, like interlamellar setae (Fig. 3H). The dorsal projection in caudal part of notogaster a parallelepiped. Eleven pairs of notogastral setae. Setae ps, and $\mathrm{ps}_{2}$ not visible in ventral or dorsal view, being smaller than the others (Fig. 3C) and hidden in a hollow between the dorsal projection and salient caudal side of notogaster. Pattern of surface of notogaster looks like distinct thin branches with interrupted lines and small spots (Fig. 3F).

Ventral side: Genital plate with serrate edges. Distinct sclerotized roller with wavy external edge stretching parallel to lateral edges of genital plate from level of its lateral angles to level of caudal edge. In middle of abdominal shield, where edges of genital and anal plates meet, is sculpturing with rounded cells. Other parts of abdominal shield covered by pattern like that on notogaster, changing into coarse granulation. Place of attachment of legs IV surrounded by large salient sclerotized combs. Above and on lateral side of anal plate sclerotized combs also present. Pori iad very 


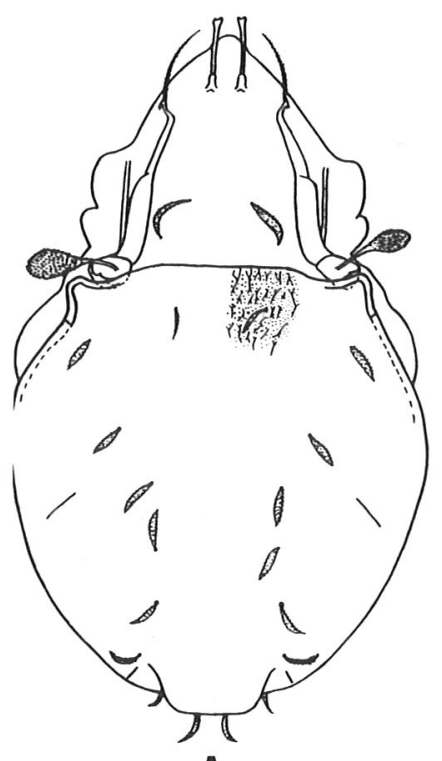

A

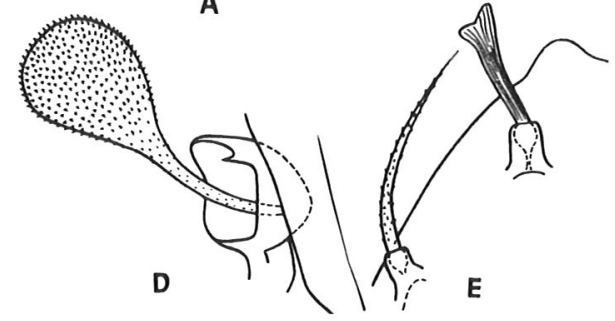

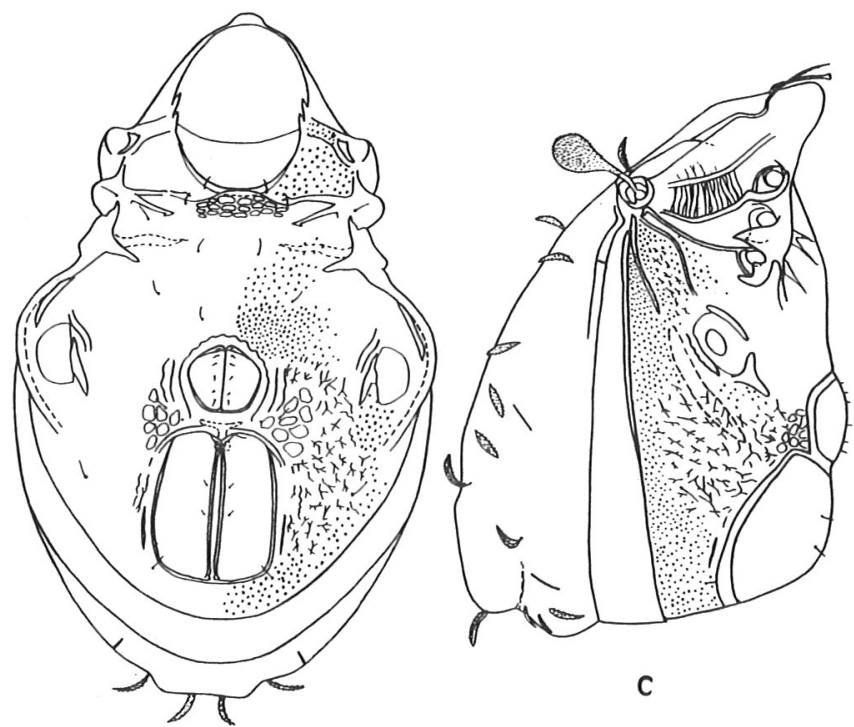

B
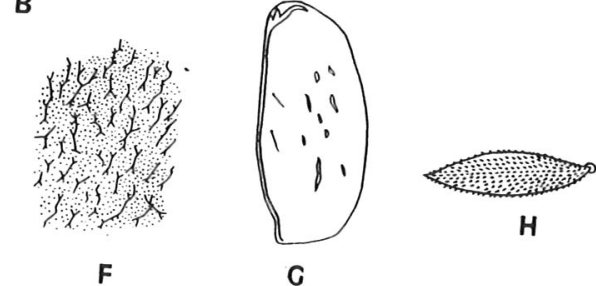

H

Fig. 3. Zetorchestes reticulatus Karppinen \& Poltavskaja sp. n. - A: dorsal view, B: ventral view, C: lateral view, D: sensilla, E: rostral and lamellar hair, F: surface of the notogaster, G: anal plate, $\mathrm{H}$ : notogastral hair.

weakly distinguished from background. All setae on ventral side thin, small and needle-like. Two pairs of anal setae. Cranial inside corner of anal plate with 2 distinct teeth (Fig. 3G).

Z. reticulatus is a deviating species in this genus. Some characteristics indicate relationship to Z. phylliterus Mahunka 1983 (see Mahunka 1983).

- lanceolate notogastral setae

- contact between genital and anal plate

- bothridia with one tooth

It differs most distinctly from Z. phylliterus in

- the form of the sensillae

- the greater width of the notogastral setae and their quantity

- the retiform sculpturing of the ventral shield

- the quantity of anal setae

- the disposition of the adanal setae
All the type material of these new species is deposited in the A. N. Severtzov Institute of Evolutionary Morphology and Ecology of Animals, Academy of Sciences of the USSR, Moscow, USSR.

\section{References}

Balogh, J. 1983: A partial revision of the Oppiidae Grandjean, 1954 (Acari: Oribatei). — Acta Zool. Acad. Sci. Hung. 29:1-3, 1-79.

Balogh, J. \& Mahunka, S. 1965: Ergebnisse der zoologischen Forschungen von Dr. Z. Kaszab in der Mongolei. 34. Acarina: Oribatei. - Ann. Hist.-Nat. Mus. Nat. Hungarici (Zool.) 57:451-465.

Mahunka, S. 1983: Some new Oribatids from Madagascar (Acari). — Folia Entomol. Hungarica 44(1):99-107.

Received 13.II.1989 